\title{
Composition of an unusual accessory polymer containing $N$-lactyl-3- amino-3,6-dideoxyhexose from walls of Bacillus megaterium NCIB 7581
}

\author{
A. H. BISHOP $\dagger$ and P. J. WHITE* \\ Department of Molecular Biology and Biotechnology, Firth Court, The University, Western Bank, \\ Sheffeld S10 $2 U H, U K$
}

(Received 11 December 1992; revised 26 April 1993; accepted 26 May 1993)

\begin{abstract}
A polysaccharide of molecular mass at least 300000 Da was isolated from walls of Bacillus megaterium NCIB 7581. Three sugars, $N$-lactyl-3-amino-3,6-dideoxyhexose, $N$-acetylglucosamine and glucose were present in equimolar proportions, and accounted for $90 \%$ of the carbon of the polysaccharide. The remainder of the polymer was an unidentified acidic molecule, with a hydrophobic nature.
\end{abstract}

\section{Introduction}

An acidic accessory polymer containing glucose and glucosamine was recognized in walls of Bacillus megaterium NCIB 7581 (preceding paper: Bishop et al., 1993). The present paper describes a further study of this polymer which has led to the identification of $N$-lactyl-3amino-3,6-dideoxyhexose as a major component.

\section{Methods}

Organisms. Bacillus megaterium NCIB 7581 and the double mutant GW-1 which requires diaminopimelate plus lysine for growth are described by Bishop et al. (1993).

Growth of bacteria, isolation of walls and of the acidic polymer. All of these procedures were as described before (Bishop et al., 1993).

Tests with lectins. The lysozyme-extracted polymer was tested against concanavalin A Type V (from Sigma) by the agar diffusion method of Goldstein \& So (1965) with Type II glycogen (Sigma) as positive control, and against Solanum tuberosum lectin with a positive control of peptidoglycan ( $B$. megaterium) from which the accessory polymer had been removed by extraction with $\mathrm{HCl}$.

Hydrolysis of the polymer. Routinely the polymer (irrespective of the method of isolation) was hydrolysed as a solution ( $3 \mathrm{mg} \mathrm{m}^{-1}$ or less) in $2 \mathrm{M}-\mathrm{HCl}$ in a sealed tube for $2 \mathrm{~h}$ in boiling water. When diaminopimelate was to be measured colorimetrically, hydrolysis was at $105^{\circ} \mathrm{C}$ in $6 \mathrm{M}-\mathrm{HCl}$ for $18 \mathrm{~h}$. Hydrolysates were dried repeatedly in a desiccator over silica gel and solid $\mathrm{NaOH}$, or else were freeze-dried. Hydrolysis for only $20 \mathrm{~min}$ in $1 \mathrm{M}-\mathrm{HCl}$ in boiling water liberated $\mathrm{N}$-lactylaminodideoxyhexose optimally.

*Author for correspondence. Tel. +44742 768555; fax +44742 728697.

$\dagger$ Present address: Department of Biological and Chemical Sciences, University of Greenwich, Wellington Street, Woolwich, London SE18, UK.
Isolation of oligosaccharides from partial hydrolysates of the polymer. Lysozyme-extracted polymer $\left(20 \mathrm{mg}\right.$ ) was kept at $100^{\circ} \mathrm{C}$ in $0.1 \mathrm{M}-\mathrm{HCl}$ $(15 \mathrm{ml})$ for $2 \mathrm{~h}$. The hydrolysate was rotary evaporated, taken up in water $(1.5 \mathrm{ml})$ and eluted with water through a column of Bio-Gel P2. Samples from fractions were assayed, and two discrete peaks of anthrone-positive material were found to emerge between the void volume and the elution volume of monosaccharides. These two impure oligosaccharide isolates were freeze-dried, and each was separately recovered from Dowex-50 with $0.5 \mathrm{M}-\mathrm{HCl}$, then eluted once more through the Bio-Gel P2 column.

Treatment of polymer with $H F$. Lysozyme-extracted polymer $(6 \mathrm{mg})$ or walls of Lactobacillus plantarum $(6 \mathrm{mg})$ were separately added to $300 \mu \mathrm{l} \mathrm{HF}(50 \%, w / v)$ at $0^{\circ} \mathrm{C}$ in a plastic tube. The mixtures were left at $0^{\circ} \mathrm{C}$ for $1 \mathrm{~h}$ with occasional shaking, then the acid was carefully neutralized with $10 \mathrm{M}-\mathrm{NaOH}$ while the temperature was kept at $0^{\circ} \mathrm{C}$. Fine adjustment to $\mathrm{pH} 7$ was done with $1 \mathrm{~m}-\mathrm{NaOH}$ and $1 \mathrm{M}-\mathrm{HCl}$, using indicator paper. The wall suspension was centrifuged and the supernatant liquid was kept. Both neutralized solutions were dried and taken up in water $(1 \mathrm{ml})$.

Separation techniques. (a) Paper chromatography. All chromatograms were developed with descending solvents (parts are $v / v$ ) on Whatman no. 1 paper. Solvents A and B were as described by Bishop et al. (1993); solvents C, D and E were from Jann et al. (1967); solvent $\mathrm{G}$ was toluene/butan-1-ol/water $(1: 9: 2$, by vol., upper phase: Renkonen \& Schindler, 1956). The two solvents for the method of Howe (1960) were also used. (b) Thin-layer chromatography. Cellulosecoated $(0 \cdot 1 \mathrm{~mm}$ thick) plates were from Merck. Solvent $\mathrm{H}$ was light petroleum (b.p. $\left.60-100^{\circ} \mathrm{C}\right) /$ ethanol $(2: 8, \mathrm{v} / \mathrm{v}$; Sykora \& Prochazka, 1953). (c) Paper electrophoresis. A Savants Instruments apparatus was used with Whatman no. 1 paper (length $52 \mathrm{~cm}$ ) across which a potential difference of 2500 to $3000 \mathrm{~V}$ was applied for $30 \mathrm{~min}$. Buffers were: for $\mathrm{pH} 9 \cdot 2,38 \mathrm{~g}$ disodium tetraborate. $10 \mathrm{H}_{2} \mathrm{O}$ in 31 water; for $\mathrm{pH} 10$, $10.8 \mathrm{ml}$ aqueous ammonia solution (sp. gr. 0.88 ) in 31 water. To reveal spots after chromatography or electrophoresis the following reagents were used: ninhydrin for amino compounds; $p$-anisidine for sugars (both used as described by Bishop et al., 1993); periodate/benzidine reagents (Gordon et al., 1956) for periodate-sensitive compounds; bromophenol blue ( $40 \mathrm{mg}$ in $95 \%, \mathrm{v} / \mathrm{v}$, aqueous ethanol, adjusted to pH 6.5) for acids, which appeared as yellow spots against a blue 
background. (d) HPLC. A Bio-Rad system was used, with the 'organic acids analysis column' (HPX $87-\mathrm{H}$ ) at room temperature and $5 \mathrm{~mm}$ $\mathrm{H}_{2} \mathrm{SO}_{4}$ as eluant (flow rate $0.5 \mathrm{ml} \mathrm{min}^{-1}$ ). When used, $\mathrm{UV}$ detection was at $210 \mathrm{~nm}$. (e) Gel-filtration. A column $(2 \times 60 \mathrm{~cm})$ of Bio-Gel P2 was used for purification and desalting of small molecules. Elution $\left(6 \mathrm{ml} \mathrm{h}^{-1}\right)$ was at room temperature, with water.

Colorimetric assays. Acetaldehyde was measured by the method of Conrad et al. (1966). The method of Ashwell et al. (1965) was used for assessment of 3-acetamido-deoxyhexoses. Diaminopimelic acid was measured by the method of Work (1957), with colour development at $37^{\circ} \mathrm{C}$ and at $\mathrm{pH}$. Formaldehyde was assayed by the method of MacFadyen (1945). Glycerol was estimated by the method of Burton (1957). Two assays were used for hexosamines: the method of Levvy \& McAllan (1959) which measures (as $N$-acetyl-derivatives) 2-aminodeoxyhexoses only (Whitehouse et al., 1954); the procedure of Rondle \& Morgan (1955) in which 3-amino-deoxyhexoses also react (without $\mathrm{N}$-acylation); for both assays glucosamine was taken as the standard. The anthrone assay, as described by Herbert et al. (1971) was used for hexoses, with glucose as standard. Hexuronic acid was measured by the method of Davidson (1966) with glucuronic acid as standard. Lactate was assayed chemically by the method of Barker (1957). The assay of Dische \& Shettles (1948) was used for 6-deoxyhexoses, with rhamnose as standard. As a general assay for sugars of many kinds, the method of Devor (1950) was employed, with glucose, glucosamine or rhamnose as standard, depending on the circumstances. Reducing sugars were assessed by a slight modification of the ferricyanide method described by Westmacott \& Perkins (1979), with glucose, glucosamine or fructose as standard; all gave the same extinction per nmol in the assay.

Enzymic assays. Glucose was measured as described by Bergmeyer \& Bernt (1965). Isomers of lactate were measured with L- and D-lactate dehydrogenases, as described by Gutmann \& Wahlfeld (1974) and Gawehn \& Bergmeyer (1974). Acetate was measured as described by Bishop et al. (1993).

Radiochemical techniques. After paper chromatography or electrophoresis of labelled material a track was cut into a strip ( $4 \mathrm{~cm}$ wide) and this was cut into pieces every $\mathrm{cm}$ down its length, then every piece was cut into four fragments. Each fragmented piece was put in water $(1 \mathrm{ml})$ in a separate scintillation vial. The vials were shaken occasionally during $30 \mathrm{~min}$ to allow elution of the radioactivity from the paper. Then Cocktail T (BDH) was added and the vials were counted in a Beckman model 1801 instrument.

Deamination of amino sugars. Monomeric amino sugars (with unsubstituted amino-groups) were deaminated with nitrous acid as described by Crumpton \& Davies (1958). After completion of this procedure, samples $(1 \mathrm{ml})$ of the reaction mixture were deionized by addition of washed Dowex-50 $\left(\mathrm{H}^{+}\right.$form, about $\left.0.5 \mathrm{~g}\right)$ with shaking for several min. Liquid was removed with a Pasteur pipette, and was added to washed Dowex-1 $\left(\mathrm{Cl}^{-}\right.$form, about $\left.0.5 \mathrm{~g}\right)$. This suspension was shaken as before and the liquid removed and freeze-dried. For attempted deamination of the lysozyme-extracted polymer $(10 \mathrm{mg}$ in $10 \mathrm{ml}$ water $), \mathrm{NaNO}_{2}(5 \mathrm{ml} ; 10 \%$, w/v) and aqueous acetic acid $(5 \mathrm{ml}$; $66 \%, \mathrm{w} / \mathrm{v}$ ) were added and left at room temperature for $30 \mathrm{~min}$. Aqueous ammonium sulphamate $(10 \mathrm{ml} ; 12.5 \%, \mathrm{w} / \mathrm{v})$ was added and left for $20 \mathrm{~min}$ to allow destruction of the nitrous acid. The mixture then was freeze-dried, taken up in water and loaded onto a column of Sephadex G-25 $(1 \times 25 \mathrm{~cm})$ that had been equilibrated with water. The column was eluted with water and fractions $(1 \mathrm{ml})$ were assayed $(50 \mu 1$ samples) with anthrone to locate the polymer. Appropriate fractions were pooled and freeze-dried, then the polymer was hydrolysed in $2 \mathrm{M}$ $\mathrm{HCl}$ for $2 \mathrm{~h}$ at $100^{\circ} \mathrm{C}$, dried, taken up in water $(4 \mathrm{ml})$, and spotted onto paper chromatograms together with deaminated glucosamine and deaminated 3-amino-6-deoxyhexose and suitable reference sugars. The solvent $(G)$ and method of development of this chromatogram was that of Renkonen \& Schindler (1956).
Periodate oxidation. Unlabelled (i.e. not radioactive) 3-amino-3,6dideoxyhexose and the unidentified acidic component of the polymer were treated with periodate at $\mathrm{pH} 5.0(50 \mathrm{mM}$-acetate buffer $)$. Oxidation of $\mathrm{N}$-acetylated $\left[{ }^{14} \mathrm{C}\right] 3$-amino-6-deoxyhexose was in $350 \mu$ water plus $35 \mu$ l sodium acetate $(0.8 \mathrm{M})$ and $15 \mu \mathrm{l}$ acetic acid $(0.8 \mathrm{M})$; solid sodium periodate $(4 \mathrm{mg})$ was added and the reaction mixture sealed in a glass tube. After overnight incubation at $4{ }^{\circ} \mathrm{C}$ the whole reaction mixture was injected into the HPLC apparatus. The consumption of periodate was assessed by the method of Dixon \& Lipkin (1954). After incubation, excess periodate was destroyed (when required), by making the solution $0.2 \mathrm{M}$ - in respect of sodium arsenite, or by adding an excess of ethane1,2-diol. A similar procedure, on a larger scale, was used for oxidation of lysozyme-extracted polymer.

Chromic acid oxidation of $O$-acetylated polymer. The procedure of Dutton \& Lim (1985) was followed with lysozyme-extracted polymer and with Ultra-Pure Agarose (BRL) as a control. This latter material is known to have alternating $\alpha$ - and $\beta$-glycosidic bonds in its structure (Rochas et al., 1986).

Reduction with $\mathrm{NaB}^{3} \mathrm{H}_{4}$. Samples $(0.5 \mathrm{ml})$ in $0.2 \mathrm{M}$-Tris $/ \mathrm{HCl}$ buffer, pH 8.4 were mixed with diglyme (100 $\mu$; Sigma) containing $\mathrm{NaB}^{3} \mathrm{H}_{4}$ (approx. $1 \times 10^{6}$ c.p.m.) and left overnight. The mixtures then were evaporated and taken up in water (to $1 \mathrm{ml}$ ).

Chemicals and enzymes. Sources of most of the special materials are described by Bishop et al. (1993). Walls were isolated from Lactobacillus plantarum (arabinosus) NCIB 6376 (grown at $37^{\circ} \mathrm{C}$ in peptone + yeast extract + glucose; each $1 \%, \mathrm{w} / \mathrm{v}$ ) after breaking the organisms by shaking them with glass beads. Charalopsis sp. muramidase was a gift from Dr J. B. Ward, by whom it was isolated. D-Lactate dehydrogenase (Lactobacillus leichmannii) and L-lactate dehydrogenase (beef heart) were from Boehringer. Amersham supplied $\mathrm{NaB}^{3} \mathrm{H}_{4}$. Professor A. C. Richardson kindly gave samples of the methylglycosides of 3-amino3,6-dideoxyglucose and of 3-amino-3,6-dideoxymannose ( $O$-acetylderivative).

\section{Results and Discussion}

\section{Properties of the intact polymer}

Molecular size. The behaviour on gel-filtration shows that the polymer is a large molecule. An estimate of its molecular mass was made by comparing the amounts of diaminopimelic acid and glucose in the enzymically extracted polymer. Sacculi of mutant GW-1, labelled with $\left[{ }^{3} \mathrm{H}\right]$ diaminopimelate (specific activity $8.9 \times$ $10^{6}$ d.p.m. $\mu \mathrm{mol}^{-1}$ ) were digested with Charalopsis muramidase (Hash \& Rothlauf, 1967), which should hydrolyse every glycosidic bond of $N$-acetylmuramic acid in peptidoglycan, and the acidic polymer was then isolated. Tritium in a sample of this material was counted; the remainder was hydrolysed with acid, and assayed enzymically for glucose. In this way the total sample of polymer was found to contain $0.77 \mathrm{nmol}$ diaminopimelate and $0.4 \mu \mathrm{mol}$ glucose. Assuming that one molecule of diaminopimelate is linked to one molecule of the accessory polymer and that glucose makes up about a quarter of the weight of the polymer (see later), then the mol. mass of the polymer would be roughly $300000 \mathrm{Da}$. The estimated value is not surprising because in another strain (M46) of B. megaterium the mol. mass of the acidic accessory polymer (made up of 
glucose, glucuronic acid and rhamnose) was $500000 \mathrm{Da}$ or more (Ivatt \& Gilvarg, 1978).

Linkage to peptidoglycan. Lysozyme-extracted polymer was treated with HF (see Methods) and then chromatographed on Sephadex G-200. The peak of anthrone-positive material coincided with the peak for diaminopimelate, which was detected by colorimetric assay after acid hydrolysis of column fractions. The ratio of diaminopimelate to anthrone-positive material in the polymer was unchanged by $\mathrm{HF}$ treatment. Polymer from mutant GW-1, labelled with $\left[{ }^{3} \mathrm{H}\right]$ diaminopimelate, was also treated with HF. Again anthrone-positive material and tritium were co-eluted from Sephadex G-200. In contrast, walls of Lactobacillus plantarum when treated with HF liberated large amounts of free glycerol, presumably from degraded teichoic acid. Its stability to HF suggests that the acidic polymer is not linked to peptidoglycan by a phosphodiester bond (cf. Ivatt \& Gilvarg, 1978; Kaya et al., 1985). The linkage was also stable (shown by methods similar to those used for treatment with $\mathrm{HF}$ ) to $4 \mathrm{M}-\mathrm{NH}_{4} \mathrm{OH}$ at $37^{\circ} \mathrm{C}$ for $2 \mathrm{~h}$. In contrast, Sasaki et al. (1983) and Kojima et al. (1985) successfully used similar conditions $(0.5 \mathrm{M}-\mathrm{NaOH}$ at $37^{\circ} \mathrm{C}$ for $30 \mathrm{~min}$ ) to break the phosphodiester bonds between teichoic acids and peptidoglycan.

\section{Chemical composition of the polymer}

Paper chromatography and electrophoresis. Acid hydrolysates of the polymer were first examined with solvent A followed by detection of sugars with $p$-anisidine (see Methods). The only obvious spots were in the positions of glucose and glucosamine. However, when periodate/ benzidine was used for detection, a white spot was seen just above the origin. In solvent $\mathbf{B}$, the material giving this spot was quite mobile $\left(R_{F} 0 \cdot 27\right)$. Once removed from brown degradation products of hydrolysis that remained near the origin with solvent $B$, the unknown material was found to give a brown spot with $p$-anisidine, and also to give a purple spot with ninhydrin. The presence of nonvolatile acids was sought by spraying chromatograms with indicator. This revealed a spot of higher mobility than any of those found with $p$-anisidine. By using the solvents and procedures of Howe (1960) this material was tentatively identified as lactic acid, and it had the same mobility on paper chromatograms as a lactate marker in several solvents. Specific enzymic methods confirmed that both L- and D-lactate were present. No free lactate was set free when the unhydrolysed polymer was kept at $\mathrm{pH} 12$ for $6 \mathrm{~h}$ at $37^{\circ} \mathrm{C}$, and so it is unlikely that $O$-lactyl-groups were present. Alkali-induced $\beta$ elimination of lactate (which is all $\mathrm{D}$-isomer) from muramic acid occurs only when the muramate has a free reducing group and is unsubstituted by amino acids (Tipper, 1969).
Electrophoresis of acid-hydrolysed ${ }^{14} \mathrm{C}$-labelled polymer at $\mathrm{pH} 10.0$ (ammonia buffer) led to a single peak of radioactivity, which migrated only slightly from the origin towards the cathode. In borate buffer ( $\mathrm{pH} 9 \cdot 2)$ three peaks of radioactivity were seen, one in the position of a glucose marker (migrated $20 \mathrm{~cm}$ towards the anode), one that had moved $8 \mathrm{~cm}$ towards the anode and which did not match any of the markers, and one in the position of glucosamine (migrated $2 \mathrm{~cm}$ towards the cathode). The unidentified peak was taken to be a borate complex of the unknown (ninhidrin- and $p$-anisidine positive) material, which must therefore contain two or more adjacent $c i$-hydroxyl groups in its molecule (Khym \& Zill, 1951).

HPLC analysis. Acid hydrolysates of the polymer, with and without subsequent $N$-acetylation (Hayashi et al., 1973) gave peaks that could be easily identified as glucose, $N$-acetylglucosamine, lactate and acetate (by comparison with the elution times of standards) and there were two other peaks. The larger of these eluted between glucose and $N$-acetylglucosamine, and was only present when the hydrolysate had been subjected to $N$ acetylation. This observation suggested that the hydrolysate contained a major quantity of an amino compound, other than glucosamine, which was removed by the guard column unless the amino function were acetylated. The smaller unknown peak eluted relatively late (29 to $30 \mathrm{~min}$ ) after injection, whether or not $\mathrm{N}$ acetylation was done. After $\mathrm{N}$-acetylation of ${ }^{14} \mathrm{C}$-labelled hydrolysate, the sum of the counts from all the peaks approximated to the total counts injected into the HPLC apparatus.

\section{Identification of the periodate-positive amino compound}

Small quantities of this unknown compound were isolated by HPLC as follows. Hydrolysates of the polymer were $\mathrm{N}$-acetylated, stripped of anionic components with Dowex-50, and injected onto the HPLC column. Fractions emerging between glucose and $\mathrm{N}$ acetylglucosamine were collected, pooled, neutralized, desalted with Dowex-50, dried and again injected into the HPLC apparatus for re-isolation.

Periodate oxidation. A purified sample of $\mathrm{N}$-acetylated unknown compound from ${ }^{14} \mathrm{C}$-labelled polymer was oxidized with periodate, and the total reaction mixture (18000 d.p.m.) was injected into the HPLC apparatus (500 $\mu 1$ sample loop). Fractions were collected (at intervals of $30 \mathrm{~s}$ ) directly into scintillation vials. Two peaks of radioactivity were found (Fig. 1), one representing approximately half as many counts as the other. This smaller peak had the same elution time as acetaldehyde; the shoulder on its side was presumably due to some unoxidized unknown compound. Confirma- 


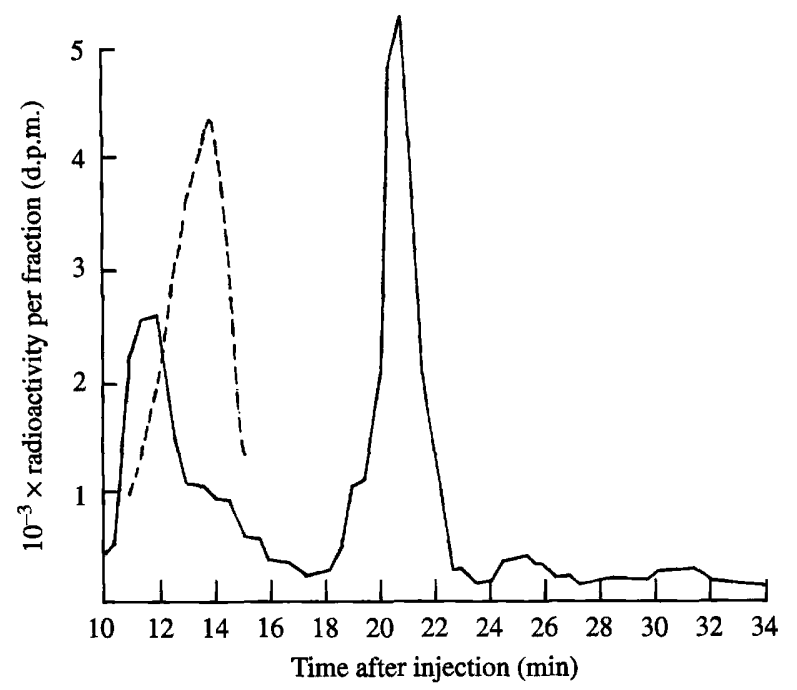

Fig. 1. HPLC analysis of products of periodate oxidation of the unknown aminosugar (generally labelled with ${ }^{14} \mathrm{C}$ ). - - Oxidized aminosugar; ---, aminosugar untreated with periodate.

tion that acetaldehyde was present was obtained in two ways. The above experiment was repeated but the fractions corresponding to the smaller peak were collected for derivatization with 2,4-dinitrophenylhydrazine. The labelled derivative was developed on a paper chromatogram (solvent $F$ ) with authentic derivatives of formaldehyde, formic acid, acetaldehyde, propionaldehyde and butyraldehyde as markers. The radioactivity had the same mobility as the derivative of acetaldehyde. In another experiment, $\mathrm{N}$-acetylated unknown compound (unlabelled, purified by HPLC and Dowex-50) was oxidized with periodate, and the reaction mixture then was assayed for acetaldehyde (positive) and for formaldehyde (negative). The production of acetaldehyde by periodate oxidation means that the substrate molecule contained a terminal methyl-group next to (usually) two hydroxylated carbon atoms. If the smaller radioactive peak were due solely to acetaldehyde (and therefore proportional in area to the radioactivity from two ${ }^{14} \mathrm{C}$-atoms) then, from its area, the larger peak would represent four ${ }^{14} \mathrm{C}$-atoms, whether or not these were present (after periodate oxidation) in a single molecule. Hence, the unknown compound might contain six carbon atoms and so be an amino derivative of a 6-deoxyhexose.

Assays for aminosugars. Hydrolysates of polymer extracted with acid from unlabelled walls were used to isolate further samples of the unknown compound. Its concentration in solution was established by assay of reducing groups (see Methods) and assuming that there was one such group per molecule. The unknown $(0.63 \mu \mathrm{mol})$ gave a colour yield equivalent to $0.31 \mu \mathrm{mol}$ of glucosamine in the assay of Rondle \& Morgan (1955), in which 2-amino- and 3-aminosugars react (though not

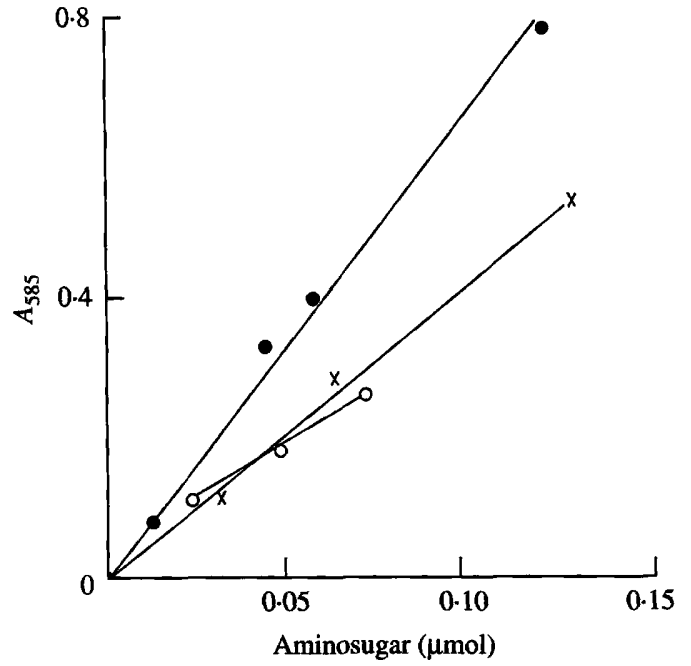

Fig. 2. Behaviour of the unknown aminosugar in the assay of Ashwell et al. (1965) for 3-aminohexoses. $\times$, Unknown aminosugar (quantified by assay of reducing groups); 0 , authentic 3-amino-3,6-dideoxyglucose (quantified by weighing and by assay of reducing groups); $O$, authentic 3-amino-3,6-dideoxymannose.

necessarily to give the same absorbance per $\mu \mathrm{mol}$ ), whereas no colour was formed in the assay of Levvy \& McAllan (1959) which is specific for 2-aminosugars. A coloured product was obtained (maximum absorbance at $555 \mathrm{~nm}$ ) in the assay of Devor (1950) in which 3aminosugars (and very many other carbohydrates) react, but 2-aminosugars do not. The unknown compound could not be a 4-amino-4,6-dideoxyhexose because the $\mathrm{N}$-acetyl-derivative of such a substance would not give acetaldehyde on periodate oxidation. Confirmation that it was a 3-aminosugar came from the assay of Ashwell et al. (1965), which is specific for this class of compounds (Fig. 2). Glucosamine alone gave no colour in this assay; a mixture of the 3-aminosugar with an excess of glucosamine, or the same amount of the 3-aminosugar alone gave the same final absorbance. As reported by Ashwell et al. (1965), the absorption spectrum of the coloured product from the 3-aminosugar in their assay was identical to that given by glucosamine when the step of periodate oxidation of glucosamine (in the assay) was omitted.

Paper chromatography. In the three solvents of Jann et al. (1967), the mobilities of the $N$-acetylated 3-aminosugar relative to fucose $(1.29,1.55,1.40$ in solvents $C, D$, $\mathrm{E}$ respectively) closely matched the published values for $\mathrm{N}$-acetyl-3-amino-3,6-dideoxyglucose. The 3-aminosugar obtained by ion-exchange chromatography (see below) had the same $R_{\text {glucose }}$ value (approx. 1.5) as 3-amino-3,6dideoxyglucose or 3-amino-3,6-dideoxymannose (released by acid hydrolysis from the authentic materials) in ethyl acetate/acetic acid/water (45:10:10, by vol.). Either $p$-anisidine or ninhydrin revealed a coloured spot 
in the same position. Glucosamine had an $R_{\text {glucose }}$ value of 0.5 in this solvent.

Ion-exchange chromatography. A sample $(1 \mathrm{ml})$ of an acid-hydrolysate $\left(2 \mathrm{M}-\mathrm{HCl}\right.$ for $2 \mathrm{~h}$ at $\left.100^{\circ} \mathrm{C}\right)$ of polymer isolated from a lysozyme digest was loaded onto a column of Dowex-50 $\left(\mathrm{H}^{+}\right.$form; $8 \%$ cross-linked; $200-400$ mesh; $1 \times 65 \mathrm{~cm}$ ) which was then eluted with $0.33 \mathrm{M}-\mathrm{HCl}$ (Gardell, 1953) while fractions $(4 \mathrm{ml})$ were collected. Assays for glucosamine (Levvy \& McAllan, 1959) and for glucosamine plus 3-aminosugar (Rondle \& Morgan, 1955) showed that glucosamine eluted alone as a broad peak when 151 to $171 \mathrm{ml}$ of liquid had emerged from the column; the 3-aminosugar appeared as a second broad peak at 191 to $203 \mathrm{ml}$. Thus, the ratio (volume at which the 3-aminosugar elutes):(volume at which glucosamine elutes) was approx. 1.3 under these conditions. This ratio has been used to identify 3-amino6-deoxyhexoses; Raff \& Wheat (1967) give values of 1.28 for 3-amino-3,6-dideoxymannose and 1.37 for 3-amino3,6-dideoxyglucose. The separated 3-aminosugar gave no colour in the assay of Levvy \& McAllan (1959), while in the assay of Rondle \& Morgan (1955) the absorption spectrum of the coloured product had a maximum at $510 \mathrm{~nm}$ rather than at $530 \mathrm{~nm}$ (the maximum found with glucosamine).

Deamination of the 3-amino-3,6-dideoxyhexose. A sample of this material $(2.84 \mu \mathrm{mol})$ was treated with nitrous acid (see Methods) and the product was assayed for 6-deoxyhexoses (see Methods) with rhamnose as standard. Maximum absorbance in the assay from both compounds was at $396 \mathrm{~nm}$, and the equivalent of $1.08 \mu \mathrm{mol}$ of 6-deoxyhexose was formed by the deamination. Another sample of the 3-amino-3,6-dideoxyhexose was deaminated and then chromatographed (solvent $G$ ). A single spot was revealed by $p$-anisidine of $R_{\text {glucose }} 2 \cdot 78$. Values of $R_{\text {glucose }}$ given by markers were: fucose (6deoxygalactose), 2.06; rhamnose (6-deoxymannose), 3.14; quinovose (6-deoxyglucose), 2.83. This experiment was repeated three times with similar results. Deamination of a 3-amino-3-deoxyhexose with nitrous acid would be expected to give a 2,3-anhydrohexose with Walden inversion at C-3 (Kent \& Whitehouse, 1955). If the product of deamination really were 6-deoxyglucose, then the amino compound itself must be a derivative of 6deoxyglucose or of its epimer, 6-deoxyallose (if isomerization occurs during reaction with nitrous acid). No source of 3-amino-3,6-dideoxyallose, or information about this compound have been traced. Taken together, all the above experiments, while not conclusive, are consistent with the identification of 3-amino-3,6-dideoxyglucose as a constituent of the polymer. Before the present work, 3-amino-3,6-dideoxyhexoses had only been found in the lipopolysaccharides of some Gram- negative bacteria (e.g. Hickman \& Ashwell, 1966; Luderitz et al., 1967; Banoub \& Shaw, 1981), where these sugars often constitute the non-reducing termini of the $O$-antigen chains. A residue of 3-amino-3,6-dideoxyhexose might perhaps form the non-reducing end of the acidic polymer from $B$. megaterium, but in this polymer the 3-amino-3,6-dideoxyhexose (by reason of its abundance) must also be part of the repeating trisaccharide unit. Although this polymer has not been proved to be antigenic or located on the outer bacterial surface, it might be that lipopolysaccharide and the Gram-positive acidic polymer have similar functions.

\section{The nature of the $N$-substituent group on residues of 3-amino-3,6-dideoxyhexose in the intact acidic polymer}

Treatment of the unhydrolysed polymer with nitrous acid did not lead to the appearance of any 6-deoxyhexose when the polymer was subsequently hydrolysed and chromatographed; instead the yield of 3-amino-3,6dideoxyglucose (and of glucosamine) appeared to be the same as from untreated polymer. Hence the aminofunctions of these two sugars in the polymer molecule must be blocked, although the amount of acetate detected in acid-hydrolysates of the polymer was much too little to account for complete substitution of both hexosamines. After the polymer had been hydrolysed for various short periods (10 to $30 \mathrm{~min})$ in $1 \mathrm{M}-\mathrm{HCl}$ at $100{ }^{\circ} \mathrm{C}$, analysis by HPLC showed that a peak in the position of $N$-acetylglucosamine was initially present but this peak diminished as the time of hydrolysis increased. These brief hydrolysates gave a positive reaction, even when the step of acetylation with acetic anhydride was omitted, in the assay of Levvy \& McAllan (1959), which is specific for $\mathrm{N}$-substituted 2-aminohexoses. Another large peak close to $\mathrm{N}$-acetylglucosamine also was only found after brief hydrolysis. This second acid-labile peak was taken to represent $N$-substituted 3-amino-3,6dideoxyhexose. Several samples of the acidic polymer were hydrolysed in $1 \mathrm{M}-\mathrm{HCl}$ for $20 \mathrm{~min}$ at $100^{\circ} \mathrm{C}$. After freeze-drying, these partial hydrolysates were passed through a column of Dowex-50 in water to remove free amino-sugars and other cationic substances. The eluate was dried, taken up in water $(300 \mu \mathrm{l})$ and all injected into the HPLC apparatus $(500 \mu \mathrm{l}$ loop). Fractions $(250 \mu \mathrm{l})$ were collected every $30 \mathrm{~s}$. Anthrone-positive material (presumably glucose) was found in fractions 8 to 10 , and a positive reaction (presumably due to $N$-acetyl-glucosamine) in the assay of Levvy \& McAllan (1959) was given by fractions 16 to 18 , but not by fractions 14 or 15 . Fractions 11 to 15 were pooled, neutralized, freeze-dried and taken up in water $(1.25 \mathrm{ml})$. The isolated material contained no detectable lactate (enzymic assays) and did not react in the assay for hexosamines of Rondle \& 
Morgan (1955). Only $0 \cdot 1 \mu \mathrm{mol} N$-substituted 2-aminohexose (presumably $N$-acetylglucosamine), and no free 2-aminohexose was detected by the assay of Levvy \& McAllan (1959). After acid hydrolysis, both lactate

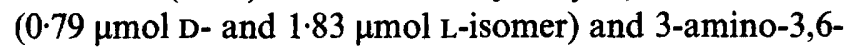
dideoxyhexose $(2.4 \mu \mathrm{mol}$ by the assay of Rondle \& Morgan, 1955) were present. Before hydrolysis, the $N$ substituted compound could be distinguished by paper chromatography (solvent $\mathrm{C}$, then periodate/benzidine reagent) from $N$-acetyl-3-amino-3,6-dideoxyhexose that had been made chemically ( $R_{\text {glucose }}$ values 0.75 and 0.69 respectively). No separation of these two compounds was achieved by HPLC with the usual operating conditions. Glucosamine, 3-amino-3,6-dideoxyhexose and lactate are found in equimolar amounts in the polymer and there is a small excess of acetate, which could come from hexosamines in residues of attached peptidoglycan. The above results show that much of the 3-aminosugar of the polymer is $N$-lactylated while much of the glucosamine is $\mathrm{N}$-acetylated. Though the formal possibility remains that some $N$-lactylglucosamine and some $\mathrm{N}$-acetyl-3-aminodideoxyhexose also occur in the polymer (though neither has been detected), this kind of variable substitution of monomer units is a most unlikely circumstance to encounter in a complex carbohydrate.

Nearly all aminosugars found in natural products are $\mathrm{N}$-acylated ; in the great majority of cases by an $\mathrm{N}$-acetylgroup. In certain actinomycetes, $\mathrm{N}$-glycolyl-muramic acid is present (Adam et al., 1969). The lipopolysaccharide of some strains of Pseudomonas aeruginosa may contain $N$-formyl-2-amino-2-deoxygalacturonic acid (Knirel et al., 1985). Pseudaminic acid carries an $N$ 3-hydroxybutyryl-substituent (Knirel et al., 1986). An $N$ lactyl-aminosugar does not seem to have been described before the present work, although muramic acid lactam (Warth \& Strominger, 1969) can be regarded as an $N$ lactyl-2-amino-2-deoxyhexose in which the lactyl-group is also linked to the aminosugar by an ether bond.

\section{The unidentified component of the polymer}

Although the accessory polymer is acidic, only acetic and lactic acids have been firmly identified in hydrolysates. The acidic functions of both of these molecules are linked to amino-groups of hexosamines in the intact polymer and so will not contribute to its acidity. The unidentified compound that eluted after lactate from the 'organic acids' column was collected from several runs of the HPLC apparatus. Counts in this peak represented about $7 \%$ of the total ${ }^{14} \mathrm{C}$ present in the polymer before hydrolysis.

This material bound to Dowex-1 (from which it could be eluted by $0.4 \mathrm{M}-\mathrm{HCl}$ ) but not to Dowex-50. It migrated towards the anode on paper electrophoresis at $\mathrm{pH} 4.5$, and could be detected as a yellow (acidic) spot with bromophenol blue. On paper chromatograms the mobility in solvent $\mathrm{A}\left(\boldsymbol{R}_{F} 0.85\right)$ was higher than that of almost all of the substances listed (over 70) by Gordon et al. (1956). By the methods of Howe (1960) the $R_{F}$ in propan-1-ol/2 $\mathrm{M}-\mathrm{NH}_{4} \mathrm{OH}(7: 3, \mathrm{v} / \mathrm{v})$ was 0.71 , and in propan-1-ol/water $(7: 3, \mathrm{v} / \mathrm{v})$ saturated with $\mathrm{SO}_{2}$ it was 0.80 , so that the $R_{\mathrm{m}}$ value was -0.61 . These data suggest that the unknown is a monocarboxylic acid which does not fall into any of the groups (i.e. unsubstituted, amino-, monohydroxy- or phenyl-) for which information was given by Howe (1960).

By integration of HPLC traces from labelled hydrolysates, the unknown acid contributes about one-third as much carbon to the polysaccharide as does glucose. If the mol. mass of the unknown is about the same as that of glucose, then only one molecule of the unknown must be present in the polymer for about every three repeating units of the trisaccharide (glucose $+N$-acetylglucosamine $+N$-lactyl-3-amino-3,6-dideoxyhexose). Partial substitution of carbohydrate polymers can occur. For example, the content of alanine in teichoic acid may vary with environmental conditions (Ellwood \& Tempest, 1972), and the extent of $O$-acetyl or ketal substitution in certain bacterial exopolysaccharides may also be incomplete (Dutton et al., 1985; Joseleau, 1985).

\section{The sequence of the monomers in the polymer}

The intact polymer did not react with lectins specific for terminal glucose or $\mathrm{N}$-acetylglucosamine. Hence these two sugars must be present within the main polymer chain, and the $N$-lactyl-3,6-dideoxyhexose (or some other compound) must be at the non-reducing terminus.

Two oligosaccharides were isolated from partial hydrolysates of the polymer. One of these (OS1) contained equimolar amounts of glucose, glucosamine and 3-amino-3,6-dideoxyhexose (and smaller quantities of the unidentified acid), and its elution volume from a column of Bio-Gel P2 suggested that it was a trisaccharide. The other (OS2) was a smaller molecule which contained equimolar 3-amino-3,6-dideoxyhexose and glucose (again with some of the unidentified acid), and this was assumed to be a disaccharide.

Reduction of OS1 with $\mathrm{NaB}^{3} \mathrm{H}_{4}$ followed by acid hydrolysis led to the appearance of two radioactive spots on paper chromatograms (solvent A). One of these corresponded to the reduction product of glucosamine, and the other to the reduction product of the unidentified acid. Glucose and 3-amino-3,6-dideoxyhexose were recovered unchanged. A similar experiment with OS2 gave the radioactive reduction products of glucose and the unidentified acid. Brief hydrolysis $\left(1 \mathrm{M}-\mathrm{HCl}\right.$ at $100^{\circ} \mathrm{C}$ for $30 \mathrm{~min}$ ) of the labelled OS2 followed by a second 
reduction with $\mathrm{NaB}^{3} \mathrm{H}_{4}$ led to the appearance on a chromatogram of four radioactive peaks, one in the position of reduced glucose, another (much smaller) in the position of reduced 3-aminodideoxyhexose, a third which was presumed to be due to the reduced unidentified acid attached to reduced glucose or aminodideoxysugar, and the fourth was due to reduced unidentified acid. A second hydrolysis $\left(2 \mathrm{M}-\mathrm{HCl}\right.$ at $100^{\circ} \mathrm{C}$ for $2 \mathrm{~h}$ ) of the labelled partial hydrolysate followed by chromatography led to the disappearance of the third radioactive spot; the peak in the position of reduced glucose was unchanged but that due to reduced aminodideoxyhexose had become of similar size to that of reduced glucose, and the amount of tritiated unidentified acid had increased. These results show that some of the unidentified acid is linked to the 3-amino-3,6-dideoxyhexose; the results do not exclude the possibility that the acid is also linked to glucose.

After treatment of the intact polymer with periodate and subsequent acid hydrolysis no glucosamine remained, but glucose and the 3-aminodideoxyhexose were recovered quantitatively. The only linkages that are consistent with these data are for $\mathrm{N}$-acetylglucosamine to be joined via C- 6 (so that C-3 and C-4 carry free hydroxyl-groups) and for glucose to be joined via C-3, or else to have more than one of its hydroxyl-groups substituted. The total quantity of the unidentified acid in the polymer is too small for it to be a frequent substituent of the glucose units, but $\mathrm{N}$-acetylglucosamine could be linked directly to glucose (structure B below) rather than to the $N$-lactyl-3-aminosugar (structure A below).

$O$-Acetylation of the polymer, followed by oxidation with chromic acid (see Methods) led to the destruction of glucosamine and the 3-aminodideoxyhexose, but glucose was recovered in undiminished quantity. The glycosidic bond of glucose is therefore in the $\alpha$-configuration; glucosamine and the 3-aminodideoxyhexose may be present as unstable $\beta$-glycosides, but whether $O$-acetylated $\alpha$-glycosides of aminohexoses are resistant to oxidation by chromic acid has not been established.

From these results, the structure of the polymer repeat unit may be:

$$
\begin{aligned}
& -N \text {-lactyl-3-amino-3,6-dideoxyhexose } \stackrel{\beta ? 1,3}{\longrightarrow} \text { Glucose } \stackrel{\alpha 1,6}{\longrightarrow} N \text {-acetylglucosamine } \stackrel{\beta ? ?}{\longrightarrow} \\
& \text { Unidentified acid (Structure A) }
\end{aligned}
$$

or else:

Unidentified acid

$N$-lactyl-3-amino-3,6-dideoxyhexose

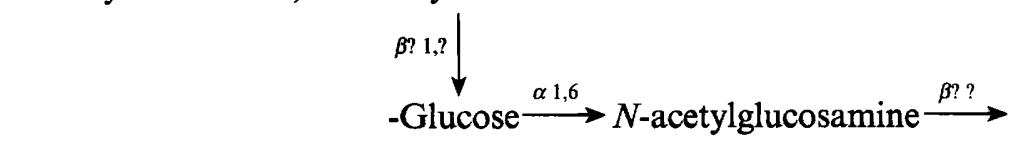

(Structure B)

\section{References}

We are grateful to the people who sent us enzymes and chemicals. A.H. B. was supported by a Studentship from the SERC.

Adam, A., Petit, J. F., Wietzerbin-Falszpan, J., Sinay, P., Thomas, D. W. \& LeDERER, E. (1969). L'acide $N$-glycolyl-muramique, constituant des parois de Mycobacterium smegmatis: identification par spectrometrie de masse. FEBS Letters 4, 87-92.

Ashwell, G., Brown, N. C. \& Volk, W. A. (1965). A colorimetric procedure for the determination of $\mathrm{N}$-acetylated-3-amino hexose. Archives of Biochemistry and Biophysics 112, 648-652.

BANOUB, J. H. \& SHAW, P. H. (1981). Isolation and characterization of 3-acetamido-3,6-dideoxyglucose from the core oligosaccharides obtained from the aquatic Gram-negative bacteria Aeromonas hydrophila and Vibrio anguillarum. Canadian Journal of Biochemistry 59, 877-879.

BARKER, S. B. (1957). Preparation and colorimetric determination of lactic acid. Methods in Enzymology 3, 241-246.

BERGMEYER, H.-U. \& BerNT, E. (1963). Determination with glucose oxidase and peroxidase. In Methods of Enzymatic Analysis, 1st edn, pp. 123-130. Edited by H.-U. Bergmeyer. New York \& London: Academic Press.

Bishop, A. H., Douglas, C. W. I., DorR, P. K. \& White, P. J. (1993). Components of the wall and capsule of Bacillus megaterium NCIB 7581. Journal of General Microbiology 139, 2723-2730.

BuRTON, R. M. (1957). The determination of glycerol and dihydroxyacetone. Methods in Enzymology 3, 246-249.

ConRad, H. E., Bamburg, J. R., Epley, J. D. \& KindT, T. J. (1966). The structure of the Aerobacter aerogenes A3 (S1) polysaccharide. II. Sequence analysis and hydrolysis studies. Biochemistry (A.C.S.) 5, 2808-2817.

Crumpton, M. J. \& Davies, D. A. L. (1958). The isolation of Dfucosamine from the specific polysaccharide of Chromobacterium violaceum (N.C.T.C. 7917). Biochemical Journal 70, 729-736.

DAvidson, E. A. (1966). Analysis of sugars found in mucopolysaccharides. Modified carbazole procedure. Methods in Enzymology 8, 55-56.

Devor, A. W. (1950). Carbohydrate tests using sulfonated $\alpha$-naphthol. Journal of the American Chemical Society 72, 2008-2012.

Dische, Z. \& SheTtLes, L. B. (1948). A specific color reaction of methylpentoses and a spectrophotometric micromethod for their determination. Journal of Biological Chemistry 175, 595-603.

DIXON, J. S. \& LIPKIN, D. (1954). Spectrophotometric determination of vicinal glycols. Application to the determination of ribofuranosides. Analytical Chemistry 26, 1092-1093.

DutTon, G. G. S. \& LiM, A. V. S. (1985). Structure of the capsular polysaccharide of Klebsiella serotype K79. Carbohydrate Research 144, 263-276.

Dutton, G. G. S., Parolis, H. \& Parolis, L. A. S. (1985). A structural investigation of the capsular polysaccharide of Klebsiella K14. Carbohydrate Research 140, 263-275. 
EllwOoD, D. C. \& TEMPEST, D. W. (1972). Effects of environment on bacterial wall content and composition. Advances in Microbial Physiology 7, 83-117.

GARDELL, S. (1953). Separation on Dowex 50 ion exchange resin of glucosamine and galactosamine and their quantitative determination. Acta Chemica Scandinavica 7, 207.

GAWEHN, K. \& BERGMEYER, H. U. (1974). D-(-)-Lactate. In Methods of Enzymatic Analysis, 2nd English edn, vol. 3, pp. 1492-1495. Edited by H. U. Bergmeyer. New York \& London: Academic Press.

GolDsteIN, I. J. \& So, L. L. (1965). Protein-carbohydrate interaction. III. Agar-gel diffusion studies on the interaction of concanavalin A, a lectin isolated from jack bean, with polysaccharides. Archives of Biochemistry and Biophysics 111, 407-414.

Gordon, H. T., ThORNBURG, W. \& WeRUM, L. N. (1956). Rapid paper chromatography of carbohydrates and related compounds. Analytical Chemistry 28, 849-855.

GutmanN, I. \& WahlFeld, A. W. (1974). L-(+)-Lactate. Determination with lactate dehydrogenase and NAD. In Methods of Enzymatic Analysis, 2nd English edn, vol. 3, pp. 1464-1468. Edited by H. U. Bergmeyer. New York \& London: Academic Press.

HASH, J. H. \& RothlaUF, M. W. (1967). The $N, O$-diacetylmuramidase of Chalaropsis species. Journal of Biological Chemistry 102, 379-388.

HaYASH, H., ARAKI, Y. \& ITO, E. (1973). Occurrence of glucosamine residues with free amino groups in cell wall peptidoglycan from bacilli as a factor responsible for resistance to lysozyme. Journal of Bacteriology 113, 592-598.

Herbert, D., Phipps, P. J. \& Strange, R. E. (1971). Chemical analysis of microbial cells. Methods in Microbiology 5, 209-344.

HickMAN, J. \& AsHWELL, G. (1966). Isolation of a bacterial lipopolysaccharide from Xanthomonas campestris containing 3acetamido-3,6-dideoxy D-galactose and D-rhamnose. Journal of Biological Chemistry 241, 1424-1428.

HowE, J. R. (1960). Paper chromatography and structural relationships of organic acids. Journal of Chromatography 3, 389-405.

IVATT, R. J. \& Gilvarg, C. (1978). Molecular structure of the teichuronic acid of Bacillus megaterium. Biochemistry (A.C.S.) 17, 3997-4003.

JANN, B., JANN, K. \& Muller-Seitz, E. (1967). A 3-amino-3,6dideoxyhexose from the lipopolysaccharide of Escherichia coli 071. Nature, London 215, 170-171.

JOSELEAU, J..P. (1985). Structural investigation of the capsular polysaccharide of Klebsiella serotype K49. Carbohydrate Research 142, 85-92.

KaYA, S., ARaki, Y. \& ITo, E. (1985). Characterization of a novel linkage unit between ribitol teichoic acid and peptidoglycan in Listeria monocytogenes cell walls. European Journal of Biochemistry 146, 517-522.

KENT, P. W. \& WhITEHOUSE, M. W. (1955). Biochemistry of the Amino Sugars, 1st edn, p. 270. London: Butterworths Scientific Publications.

KHYM, J. X. \& ZiLL, L. P. (1951). The separation of sugars by ion exchange. Journal of the American Chemical Society 74, 2090-2094.

Knirel, Y. A., Vinogradov, E. V., Shashkov, A. S., Dimitriev, B. A., Kochetkov, N. K., Stanislavsky, E. S. \& Mashilova, G. M. (1985). Somatic antigens of Pseudomonas aeruginosa. The structure of the $O$-specific polysaccharide chains of lipopolysaccharides of $P$. aeruginosa $\mathrm{O} 4$ (Lanyi) and related serotype O6 (Habs) and immunotype 1 (Fisher). European Journal of Biochemistry 150, 541-550.

Knirel, Y. A., Vinogradov, E. V., ShashKov, A. S., Dimitriev, B. A., Kochetkov, N. K., Stanislavsky, E. S. \& Mashilova, G. M. (1986). Somatic antigens of Pseudomonas aeruginosa. The structure of $O$-specific polysaccharide chains of $P$. aeruginosa 010 (Lanyi) lipopolysaccharides. European Journal of Biochemistry 157, 129-138.

KoJIMA, N., ARAKI, Y. \& ITO, E. (1985). Structural studies on the acidic polysaccharides of Bacillus cereus AHU 1356 cell walls. European Journal of Biochemistry 148, 479-484.

Levvy, G. A. \& MCAllan, A. (1959). The $N$-acetylation and estimation of hexosamines. Biochemical Journal 73, 127-132.

Luderitz, O., RuschmanN, E., WestPhal, O., RafF, R. \& Wheat, W. (1967). Occurrence of 3-amino-3,6-dideoxyhexose in Salmonella and related bacteria. Journal of Bacteriology 93, 1681-1687.

MACFADYEN, D. A. (1945). Estimation of formaldehyde in biological mixtures. Journal of Biological Chemistry 158, 107-135.

RAFF, R. A. \& WheAT, R. W. (1967). Characterization of 3-amino-3,6dideoxy-D-glucose from a bacterial lipopolysaccharide. Journal of Biological Chemistry 242, 4610-4613.

RENKonen, O. \& SCHINDLER, O. (1956). Papierchromatographische Trennung der naturlichen 2-Deoxyhemamethylosen und deren 3Methylather. Helvetica Chimica Acta 39, 1490-1493.

Rochas, C., Lahaye, M., Yaphe, W. \& VIET, M. J. P. (1986). ${ }^{13}$ CN.M.R.-spectroscopic investigation of agarose oligomers. Carbohydrate Research 148, 199-207.

RoNDle, C. J. M. \& MORGAN, W. T. J. (1955). The determination of glucosamine and galactosamine. Biochemical Journal 61, 586-589.

SaSAKI, Y., ARAKI, Y. \& ITO, E. (1983). Structure of teichoicacid-glycopeptide complexes from cell walls of Bacillus cereus AHU 1030. European Journal of Biochemistry 132, 207-213.

SyKora, V. \& Prochazka, Z. (1953). Identifikace 2,4-dinitrofenylhydrazonukarbonylovych sloucenin papirovou chromatografii. Chemicke Listy 47, 1674-1675.

TIPPER, D. J. (1968). Alkali-catalysed elimination of D-lactic acid from muramic acid and its derivatives and the determination of muramic acid. Biochemistry (A.C.S.) 7, 1441-1449.

WARTH, A. D. \& STrominger, J. L. (1969). Structure of the peptidoglycan of bacterial spores: occurrence of the lactam of muramic acid. Proceedings of the National Academy of Sciences of the United States of America 64, 528-535.

WestmacotT, D. \& Perkins, H. R. (1979). Effects of lysozyme on Bacillus cereus 569: rupture of chains of bacteria and enhancement of sensitivity to autolysins. Journal of General Microbiology 115, $1-11$.

White, P. J. \& GILVARG, C. (1977). A teichuronic acid containing rhamnose from cell walls of Bacillus megaterium. Biochemistry (A.C.S.) 16, 2428-2435.

Whitehouse, M. W., Kent, P. W. \& Pasternak, C. A. (1954). Acyclic derivatives of amino-sugars. Journal of the Chemical Society 2315-2317.

WoRK, E. (1957). Reaction of ninhydrin in acid solution with straight chain aminoacids containing two amino groups and its application to the estimation of $\alpha, \varepsilon$-diaminopimelic acid. Biochemical Journal 67 , 416-423. 